\title{
UVBR-induced DNA damage in natural marine picoplankton assemblages in the tropical Atlantic Ocean
}

\author{
Peter Boelen ${ }^{1,2, *}$, M. Karin de Boer ${ }^{1}$, Gijsbert W. Kraay ${ }^{2}$, Marcel J. W. Veldhuis ${ }^{2}$, \\ Anita G. J. Buma ${ }^{1}$ \\ ${ }^{1}$ Department of Marine Biology, Centre for Ecological and Evolutionary Studies, University af Groningen, PO Box 14, \\ 9750 AA Haren, The Netherlands \\ ${ }^{2}$ Department of Biological Oceanography, Netherlands Institute for Sea Research, PO Box 59, 1790 AB Den Burg, Texel,
} The Netherlands

\begin{abstract}
UVBR (ultraviolet-B radiation: 280 to $315 \mathrm{~nm}$ )-induced DNA damage, measured as cyclobutane pyrimidine dimers (CPDs), was determined in size fractions of natural populations of bacterio- and phytoplankton collected in marine tropical waters. Mean biologically effective UVBR doses in the wind-mixed layer were calculated from DNA dosimeter data. Phytoplankton species composition in these waters was monitored using flow cytometry and pigment analyses. In terms of (divinyl-jchlorophyll a concentrations, prochlorophytes and cyanobacteria comprised the largest fraction of the phytoplankton, except in a eutrophic bay at Curaçao, an island located in the southern Caribbean. In terms of cell numbers and amount of DNA, small prochlorophytes and marine bacteria dominated. Small but detectable levels of UVBR-induced DNA damage were found at all locations. In general, more DNA damage was found in the small size fraction $(0.2$ to $1 \mu \mathrm{m})$ than in the larger size fraction (1 to $10 \mu \mathrm{m})$. The greatest amount of damage was found in the small size fraction collected in the central Atlantic Ocean (20 CPDs $/ 10^{6}$ nucleotides), despite the fact that UVBR doses were much higher at other locations. The calculated mean biologically effective UVBR doses in the wind-mixed layer were 2 to 17 times lower as compared with incident UVBR doses. CPD levels determined in cultures of the cyanobacterium Synechococcus sp. subjected to UVBR doses similar to those in the wind-mixed layer corresponded with CPD levels measured in the 1 to $10 \mu \mathrm{m}$ fraction in the field. Our results indicate that UVBR vulnerability is size dependent. Furthermore, the low CPD levels observed in these field communities may be explained by the low mean biologically effective doses received by the cells as a result of wind-induced mixing.
\end{abstract}

KEY WORDS: Cyclobutane pyrimidine dimers . DNA damage - Marine bacteria - Phytoplankton . Synechococcus sp. WH7803 - Ultraviolet-B radiation · UVBR

\section{INTRODUCTION}

In tropical oceanic waters UVBR (ultraviolet-B radiation: 280 to $315 \mathrm{~nm}$ ) penetrates to several tens of meters (Smith \& Baker 1979). In a previous study we used a DNA biodosimeter to measure the penetration of biologically effective (in this case DNA damaging) UVBR in the central Atlantic Ocean and in several

•E-mail: p.boelen@biol.rug.nI water types around Curaçao, Netherlands Antilles (Boelen et al. 1999). It was shown that biologically effective UVBR may penetrate deep into these waters, giving $1 \%$ levels down to $25 \mathrm{~m}$. This low attenuation, together with the high natural UVBR levels in these regions, may have an impact on organisms that are present in these waters. Such stress can result in a decrease in primary (Behrenfeld et al. 1993) or bacterial production (Aas et al. 1996, Jeffrey et al. 1996a,b, Visser et al. 1999), the induction of UV absorbing com- 
pounds (Shibata 1969, Wood 1987, Drollet et al. 1993), or damage to essential macromolecules, e.g. DNA (Jeffrey et al. 1996a,b, Lyons et al. 1998, Wilhelm et al. 1998, Visser et al. 1999).

Structural changes in DNA are considered to be one of the primary consequences of the deleterious effects of UVBR on the cellular level (Karentz et al. 1991, Buma et al. 1995). Cyclobutane pyrimidine dimers (CPDs), especially thymine dimers ( $\mathrm{T}<>\mathrm{T}$ ) are the predominant lesions induced by UVBR (Tyrrell 1986). These photoproducts block transcription and replication of the DNA and cause mutations or even cell death (Setlow et al. 1963, Swenson \& Setlow 1966).

In the current paper we report on the presence of CPDs in DNA isolated from phytoplankton and bacterioplankton samples in the central Atlantic Ocean and in several water types around Curaçao, the Netherlands Antilles. To relate these results to UVBR doses the cells may have received, mean biologically effective doses were calculated, taking into account windinduced mixing. Also, a comparison was made with results from laboratory experiments, where a typical marine picophytoplankter from tropical oceanic waters, Synechococcus sp. WH7803, was exposed to increasing levels of UVBR.

\section{MATERIALS AND METHODS}

Sampling sites. The experiments were carried out in 1996 in several water types around Curaçao and at several stations during the 1996 'Deep Chlorophyll
Table 1. Sampling dates and locations

\begin{tabular}{|llccc|}
\hline Code & Location & $\begin{array}{c}\text { Latitude } \\
\left({ }^{\circ} \mathrm{N}\right)\end{array}$ & $\begin{array}{c}\text { Longitude } \\
\left({ }^{\circ} \mathrm{W}\right)\end{array}$ & $\begin{array}{c}\text { Date } \\
(1996)\end{array}$ \\
\hline st300 & DCM cruise & 22 & 38 & 13 Aug \\
st400 & DCM cruise & 34 & 33 & 20 Aug \\
st500 & DCM cruise & 34 & 22 & 26 Aug \\
AB1 & Curaçao, Anna Bay & 12 & 69 & 14 Nov \\
PB1 & Curaçao, Pest Bay & 12 & 69 & 7 Nov \\
OO1 & Curaçao, open ocean & 12 & 69 & 11 Nov \\
\hline
\end{tabular}

Maximum' (DCM) expedition of RV 'Tydeman' in the central Atlantic Ocean (Fig. 1). Detailed station information is summarized in Table 1. Samples (4 l) of water were collected at several depths using Niskin bottles during the middle of the day and immediately filtered through 10, 1 and $0.2 \mu \mathrm{m}$ polycarbonate filters (Poretics). The 1 and $0.2 \mu \mathrm{m}$ filters were frozen in liquid nitrogen and stored at $-80^{\circ} \mathrm{C}$ until DNA isolation.

Samples for flow cytometer analysis (described later) were collected at the central Atlantic stations in the middle of the day. Samples $(2 \mathrm{ml})$ were analyzed immediately or fixed with $0.5 \%$ paraformaldehyde (final concentration), frozen in liquid nitrogen and stored at $-80^{\circ} \mathrm{C}$ until further analyses.

Culture conditions. A culture of the cyanobacterium Synechococcus sp. WH7803 was obtained from the Provasoli-Guillard National Center for Culture of Phytoplankton (CCMP 1334). The cells were grown in artificial sea water supplied with $\mathrm{H} / 2$ nutrients (Guillard 1975) in temperature-controlled $\left(22^{\circ} \mathrm{C}\right)$ quartz

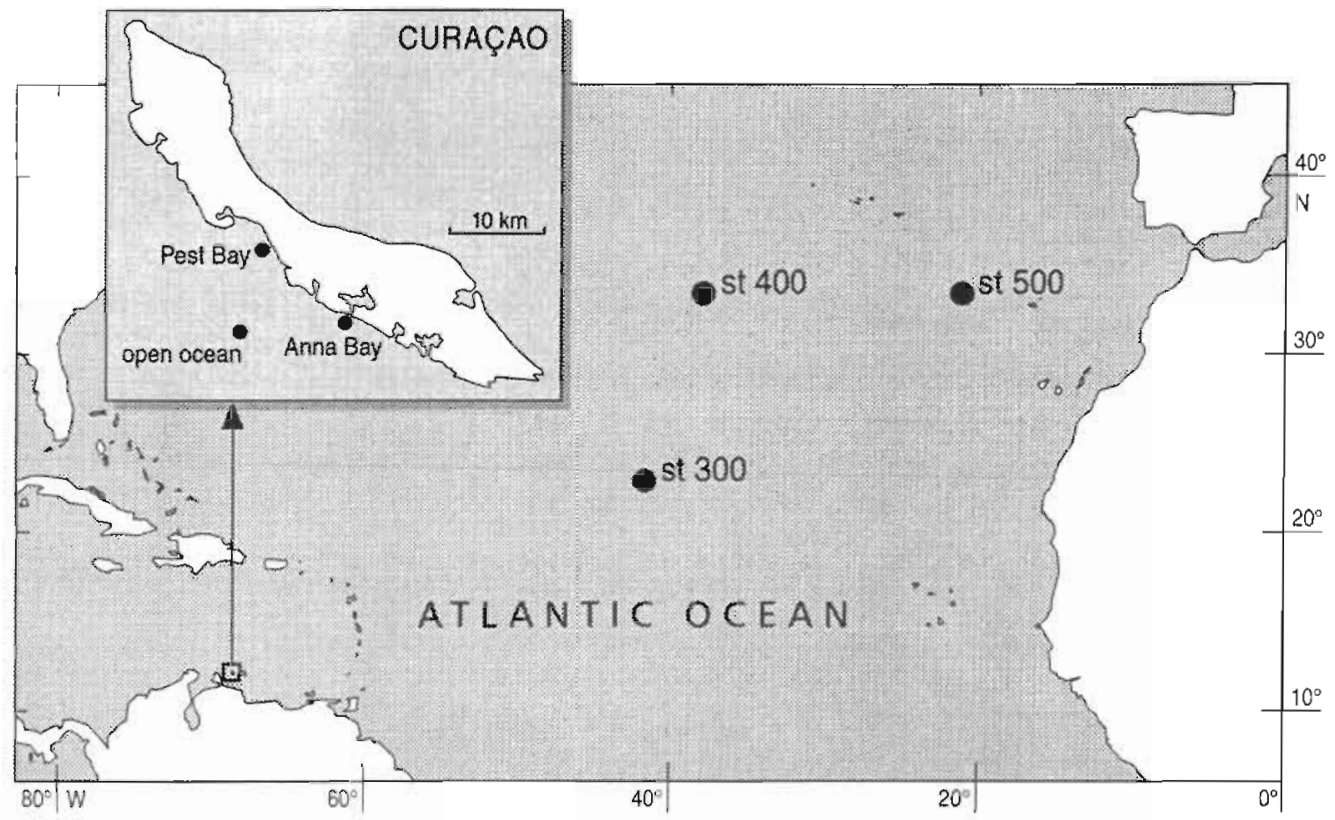

Fig. 1. Sample locations during the 1996 'Deep Chlorophyll Maximum' (DCM) research cruise and at Curaçao (inset) 
cuvettes $(500 \mathrm{ml})$. The cultures were kept in suspension by gentle stirring. The cuvettes were illuminated from 1 side with $50 \mathrm{~W}$ halogen lamps to provide photosynthetically active radiation (PAR) $(14 \mathrm{~h}$ light:10 h dark), giving approximately $350 \mu \mathrm{mol} \mathrm{m} \mathrm{m}^{-2} \mathrm{~s}^{-1}$ (Table 2 ). After $3 \mathrm{~d}$ of acclimation to these PAR levels the cultures were exposed additionally to 2 UVAR fluorescent tubes (Philips $09 \mathrm{~N}$ ) and 2 UVBR tubes (Philips TL 12) for $6 \mathrm{~h} \mathrm{~d}^{-1}$ in the middle of the light period. UVCR $(200$ to $280 \mathrm{~nm}$ ) was removed using $3 \mathrm{~mm} 305$ Schott cut-off filters. The intensity of UVR received by the cultures was varied by changing the distance between the UVR sources and the cuvettes. The amount of UVBR, UVAR ( 315 to $400 \mathrm{~nm}$ ) and PAR ( 400 to $700 \mathrm{~nm}$ ) was measured using a MACAM SR9910 double monochromator scanning spectroradiometer (Macam Photometrics) equipped with a $4.2 \mathrm{~m}$ quartz cable connected to a $4 \pi$-collector. Spectra were recorded at $1 \mathrm{~nm}$ intervals between 280 and $400 \mathrm{~nm}$ and at $5 \mathrm{~nm}$ intervals between 400 and $700 \mathrm{~nm}$. Biologically effective doses (BEDs) were calculated from the spectra using the DNA action spectrum of Setlow (1974) normalized at $300 \mathrm{~nm}$ (Table 2).

Cells were counted daily using a Coulter counter. Cultures were not axenic, the average amount of bacteria was $12 \%$ of the total biovolume. There was no measurable difference in growth rate (mean of $0.6 \mathrm{~d}^{-1}$ ) between the cuvettes. Cells were harvested on the 5 th day of UVR treatment before (09:30 h), in the middle $(13: 00 \mathrm{~h})$ and at the end $(16: 00 \mathrm{~h})$ of the UVR-exposure period. Aliquots $(50 \mathrm{ml})$ of culture were filtered over a Whatman GF/F filter. The filter was immediately frozen in liquid nitrogen and stored at $-80^{\circ} \mathrm{C}$ until further treatment.

DNA isolation and quantification. DNA was extracted from filters using a method modified method from Doyle \& Doyle (1991). The filters were incubated at $60^{\circ} \mathrm{C}$ for $30 \mathrm{~min}$ with $750 \mu \mathrm{l}$ preheated CTAB isolation buffer $(2 \%[\mathrm{w} / \mathrm{v}$ ] CTAB [Sigma], $1.4 \mathrm{M} \mathrm{NaCl}, 0.2 \%$ [v/v] 2-mercaptoethanol, $20 \mathrm{mM}$ EDTA, $100 \mathrm{mM}$ Tris$\mathrm{HCl} \mathrm{pH}=8.0$ ). Then $750 \mu \mathrm{l} \mathrm{CIA}$ (chloroform/isoamylalcohol [24:1]) was added to extract the DNA from cell debris and proteins. The solution was shaken briefly and subsequently centrifuged in an Eppendorf cen- trifuge at maximum speed $(20000 \times g)$ for $10 \mathrm{~min}$. The upper (water) phase was transferred to a clean vial and around $0.5 \mathrm{ml}$ ( $2 / 3$ of total volume) cold isopropanol was added to precipitate the DNA. This mixture was shaken gently, incubated for $1 \mathrm{~h}$ at $4^{\circ} \mathrm{C}$ and centrifuged $30 \mathrm{~min}$ at $4^{\circ} \mathrm{C}$. The supernatant was removed carefully and $1 \mathrm{ml}$ of $80 \%$ ice-cold ethanol was added to the precipitated nucleic acids. The vials were placed at $-20^{\circ} \mathrm{C}$ for $15 \mathrm{~min}$ and centrifuged for $30 \mathrm{~min}$ $(20000 \times g)$. The DNA was dried under vacuum and resuspended in $0.1 \times \mathrm{TE}$ buffer $(1 \mathrm{mM}$ Tris- $\mathrm{HCl} \mathrm{pH}=$ 8.0, $0.1 \mathrm{mM}$ EDTA). To remove RNA, the DNA was incubated for $1 \mathrm{~h}$ with $75 \mu \mathrm{g} \mathrm{ml}^{-1}$ RNase (Boehringer Mannheim) at room temperature.

The amount of DNA was determined fluorometrically using Picogreen dsDNA quantitation reagent (dilution 1:400, Molecular Probes) on a 1420 Victor multilabel counter (EG\&G Wallac, excitation $485 \mathrm{~nm}$, emission $535 \mathrm{~nm}$ ).

Quantification of cyclobutane pyrimidine dimers. The amount of CPDs in DNA was determined using an immunodotblot procedure (Boelen et al. 1999). In brief, heat-denaturated DNA samples (0.06 to $1000 \mathrm{ng}$ ) were blotted onto a nylon membrane. To detect CPDs, the membrane was incubated with the primary antibody H3 (Roza et al. 1988). This was followed by an incubation with the secondary antibody (rabbit antimouse) coupled to alkaline phosphatase. Chemiluminiscent detection was done using Lumi-Phos Plus (GibcoBRL) in combination with a photographic film. The $\mathrm{H} 3$ antibody is raised against cyclobutane thymine dimers but also has a high affinity for 5'TC dimers (Fekete et al. 1998). To allow quantification of the amount of damage in the sample DNA, the samples were compared with a dilution series of standard DNA. The amount of CPDs in the standard DNA was determined before by calibrating it against DNA isolated from irradiated Hela cells, kindly provided by Dr Len Roza. The amount of CPDs in this DNA was determined by Roza et al. (1988) by means of HPLC. The detection limit of the CPD assay is $<1 \mathrm{CPD} / 10^{6}$ nucleotides.

Calculation of mixing depth and mean doses. To estimate the daily BED that the plankton actually

Table 2. Irradiance conditions during UVR-treatments. Biologically effective UV-dose (BED) weighted with the action spectrum of Setlow (1974), normalized at $300 \mathrm{~nm}$

\begin{tabular}{|lcccr|}
\hline Cuvette no. & UVBR $\left(\mathrm{W} \mathrm{m}^{-2}\right)$ & UVAR $\left(\mathrm{W} \mathrm{m}^{-2}\right)$ & PAR $\left(\mu \mathrm{mol} \mathrm{m}^{-2} \mathrm{~s}^{-1}\right)$ & $\mathrm{BED}\left(\mathrm{J} \mathrm{m}^{-2} \mathrm{~d}^{-1}\right)$ \\
\hline 1 & 0 & 0.33 & 345 & 0 \\
2 & 0.076 & 1.4 & 370 & 300 \\
3 & 0.15 & 2.9 & 370 & 900 \\
4 & 0.30 & 4.6 & 340 & 1600 \\
5 & 0.54 & 7.8 & 390 & 2900 \\
\hline
\end{tabular}


Table 3. Calculated mean daily biologically effective doses $\left(B E D_{m}\right)$ at the sampling sites, taking into account wind-induced vertical mixing. Biologically effective dose just below the surface $\left(B E D_{0}\right)$ and attenuation coefficient for the induction of $D N A$ damage $\left(K_{\mathrm{d}}\right)$ were measured using a DNA dosimeter (Boelen et al. 1999). The depth of the wind-mixed layer (WML) was estimated using the wind speed $\left(W_{10}\right)$. Depth of the calculated. wind-mixed layer exceeded the actual depth in the bays: here real depths were used to calculate $B E D_{m}$

\begin{tabular}{|c|c|c|c|c|c|c|}
\hline Code & Location & $\mathrm{BED}_{0}\left(\mathrm{~J} \mathrm{~m}^{-2} \mathrm{~d}^{-1}\right)$ & $K_{\mathrm{d}}\left(\mathrm{m}^{-1}\right)$ & $W_{10}\left(\mathrm{~m} \mathrm{~s}^{-1}\right)$ & WML (m) & $\mathrm{BED}_{\mathrm{m}}\left(\mathrm{J} \mathrm{m}^{-2} \mathrm{~d}^{-1}\right)$ \\
\hline st300 & DCM cruise & 884 & 0.18 & 8 & 20 & 239 \\
\hline st400 & DCM cruise & 592 & 0.20 & 10 & 25 & 118 \\
\hline st500 & DCM cruise & 456 & 0.18 & 3 & 7.5 & 250 \\
\hline$A B 1$ & Curaçao, Anna Bay & 880 & 1.60 & 6 & $10^{\circ}$ & 55 \\
\hline PB1 & Curaçao, Pest Bay & 2263 & 0.26 & 7 & $15^{\circ}$ & 569 \\
\hline 001 & Curaçao, open ocean & 2235 & 0.35 & 6 & 15 & 423 \\
\hline
\end{tabular}

received at the various sampling sites, the depth of the wind-mixed layer was combined with the attenuation coefficient and the dose just under the surface (Table 3).

Subsurface doses and attenuation coefficients were determined using a DNA dosimeter (Boelen et al. 1999). In short, small acid-cleaned quartz tubes were filled with a solution of $10 \mu \mathrm{g} \mathrm{ml}^{-1}$ calf thymus DNA (Sigma) in TE-buffer $(10 \mathrm{mM}$ Tris- $\mathrm{HCl} \mathrm{pH}=8.0,1 \mathrm{mM}$ EDTA). The tubes were sealed with parafilm, after which duplicate tubes were incubated at several water depths during a period of the day. After incubation, the tubes were kept in the dark at $4^{\circ} \mathrm{C}$ during transportation. Subsequently, the DNA solution was stored at $-20^{\circ} \mathrm{C}$ until CPD analyses. Calibration of biodosimeter levels was done by use of an underwater, doublemonochromator, scanning spectroradiometer (Macam Photometrics), equipped with a 4.2 m quartz cable connected to a $4 \pi$-collector. The conversion factor between scalar irradiance and the DNA dosimeter was: $1 \mathrm{CPD}$ per million nucleotides $=3.1 \mathrm{~J} \mathrm{~m}^{-2}$ (Setlow weighted, $\mathrm{N}=300$ ) (Boelen et al. 1999).

Average biologically effective attenuation coefficients $\left(K_{\mathrm{d}}\right)$ were determined from linear regressions of natural logarithmic biologically effective irradiation against depth using the log linear part of the curve. The daily doses at $0 \mathrm{~m}\left(B E D_{0}\right)$ were calculated by extrapolating the curves to the surface. Daily doses were expressed in $\mathrm{J} \mathrm{m}^{-2} \mathrm{~d}^{-1}$ (Setlow weighted, normalized at $300 \mathrm{~nm}$ ) by using the conversion factor 3.1, as described above.

Depth of the wind-mixed layer (WML, in m) was estimated by calculating half of the Ekman depth $D_{E}$ (Veth 1991):

$$
\mathrm{WML}=0.5 D_{\mathrm{E}} \approx 2.5 W_{10}
$$

where $W_{10}=$ wind speed $\left(\mathrm{m} \mathrm{s}^{-1}\right)$ at standard height $(10 \mathrm{~m})$. The calculated values for WML corresponded with occasionally measured CTD profiles (C. Veth pers. comm., data not shown).
Mean biologically effective doses $\left(B E D_{m}\right)$ were calculated assuming constant attenuation as

$$
\mathrm{BED}_{\mathrm{m}}=\frac{\mathrm{BED}_{0}\left(1-\mathrm{e}^{\left(-k_{\mathrm{d}} W M L\right)}\right)}{\bar{K}_{\mathrm{d}} \mathrm{WML}}
$$

(Helbling et al. 1994), where BED $=$ biologically effective daily dose just below the surface and $K_{d}=$ attenuation coefficient for induction of DNA damage.

Pigment composition. In order to estimate phytoplankton composition, 10 l samples of water were filtered over a Whatman GF/F glass-fiber filter. Near Curaçao the samples were collected at the surface. At the cruise stations samples were collected at different depths between 5 and $30 \mathrm{~m}$. The filters were frozen immediately in liquid nitrogen and stored at $-80^{\circ} \mathrm{C}$ until further analyses. Pigments were determined by HPLC as described by Kraay et al. (1992). Divinylchlorophyll a concentrations were determined as described by Veldhuis \& Kraay (1990). Phytoplankton class abundances were calculated from the pigment data using the CHEMTAX program, as introduced by Mackey et al. (1996).

Flow cytometry. At the stations st300, st400 and st500 in the central Atlantic Ocean (Fig. 1) species composition and relative DNA content per species cluster were determined using a flow cytometer (Coulter XL-MCL or Elite-ESP) in combination with the nucleic acid stain Picogreen, as described by Veldhuis et al. (1997). Four clusters were identified: heterotrophic bacteria, Prochlorococcus sp., Synechococcus sp. and small eukaryotic algae.

These data were used to calculate the relative contribution, in terms of cell numbers and amount of DNA, of the species groups which were collected on the filters used for DNA isolation. We assumed that all the heterotrophic bacteria and Prochiorococcus sp. cells were retained on the $0.2 \mu \mathrm{m}$ filter, whereas Synechococcus sp. and eukaryotic algae were retained on the $1 \mathrm{~mm}$ filter. This gives an indication of which species groups contributed most to the total amount of DNA damage. 
The actual contribution is difficult to predict since there may be differences in sensitivity to DNA damage and yield of DNA isolation between the various groups.

\section{RESULTS}

\section{Dose-response experiments}

A UVBR dose-related induction of CPDs was found in cultures of the marine picophytoplankter Synechococcus sp. WH7803 (Fig. 2). In general, CPD levels increased during UVR treatment as well as with increasing UVR intensity. No signal was found in Synechococcus cells not exposed to UVR. The highest level of photoproducts (60 to $70 \mathrm{CPDs} / 10^{6}$ nucleotides) was found at the end of the UVR treatment in the culture exposed to the highest BED $\left(2900 \mathrm{~J} \mathrm{~m}^{-1} \mathrm{~d}^{-1}\right)$. Samples taken just prior to the daily UVR treatment showed residual DNA damage. This indicates that at the given PAR levels and UVR doses not all damage was repaired between UVR treatments.

\section{Species composition at field locations}

In terms of (divinyl-)chlorophyll a concentrations, prochlorophytes (Prochlorococcus sp.) and cyanobacteria (Synechococcus sp.) comprised the largest fraction of the phytoplankton, except at the eutrophic Anna Bay station off Curaçao (Table 4). At this station chlorophyll a concentrations were substantially higher and diatoms, dinoflagellates and cyanobacteria formed the bulk of the phototrophic community.

At the central Atlantic stations, heterotrophic bacteria and Prochlorococcus sp. dominated in terms of cell numbers and DNA quantity, as measured by flow cytometry (Table 5). Typically, more then $97 \%$ of the total DNA content originated from these small organisms at the central Atlantic stations. When these data were subdivided into 2 size classes, the smallest size

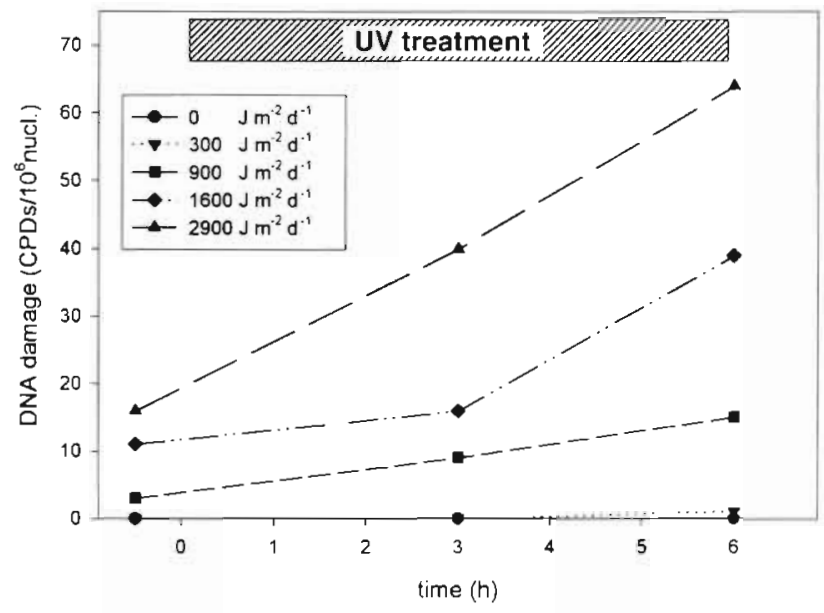

Fig. 2. Dose-response curves for the induction of CPDs in cultures of Synechococcus sp. WH7803. Biologically effective doses were calculated using the DNA action spectrum of Setlow (1974), normalized at $300 \mathrm{~nm}$ (Table 2). Cells were harvested on the 5th day of UVR treatment before $(09.30 \mathrm{~h})$, in the middle $(13: 00 \mathrm{~h})$ and at the end $(16: 00 \mathrm{~h})$ of the UVR exposure period

fraction $(<1 \mu \mathrm{m})$ consisted of $62 \%$ heterotrophic bacteria and $38 \%$ prochlorophytes, in terms of DNA content. In the fraction $>1 \mu \mathrm{m}$, cyanobacteria and eukaryotic algae each contributed $50 \%$ to the total amount of DNA (Table 6).

\section{UVR levels at field locations}

The BEDs just underneath the surface at the sample locations varied between 456 and $2263 \mathrm{~J} \mathrm{~m}^{-2} \mathrm{~d}^{-1}$ (Table 3). The central Atlantic waters (st 300 to st500) appeared to be most transparent for UVBR, with biologically effective attenuation coefficients between 0.18 and $0.2 \mathrm{~m}^{-1}$. Waters off Curaçao were also shown to be UVBR-transparent, except the eutrophic Anna Bay (Table 3).

The calculated wind-mixed layer varied between 7.5 and $20 \mathrm{~m}$ (Table 3). In those cases where the calculated

Table 4. Estimated contributions of various phytoplankton classes at the sample sites. The contribution is expressed in nanograms of (divinyl-)chlorophyll a per liter as determined by interpretation of pigment HPLC data using the CHEMTAX program. Values shown for the Tydeman stations (st300, st 400 and st500) are averaged values of samples collected between 5 and $30 \mathrm{~m}$

\begin{tabular}{lrrrrrrrr} 
Stn & Prochlorophytes & Cyanobacteria & Dinoflagellates & Diatoms & Prymnesiophytes & Chrysophytes & Chlorophytes Cryptophytes \\
\hline st300 & 13 & 22 & 0 & 0 & 11 & 3 & 0 & 0 \\
st400 & 13 & 21 & 0 & 0 & 11 & 3 & 0 & 1 \\
st500 & 13 & 23 & 0 & 0 & 12 & 4 & 0 \\
AB1 & 0 & 2622 & 1789 & 901 & 65 & 253 & 309 & 62 \\
PB1 & 51 & 22 & 0 & 0 & 7 & 3 & 5 \\
OO1 & 78 & 94 & 15 & 17 & 28 & 13 & 18 \\
\hline
\end{tabular}


Table 5. Relative contribution, in cell numbers and amount of DNA, of 4 species clusters as analyzed by flow cytometry at the Tydeman stations. Shown are averaged values of 4 or 5 samples collected between 0 and $40 \mathrm{~m}$

\begin{tabular}{|c|c|c|c|c|c|c|c|c|}
\hline \multirow[t]{2}{*}{ Stn } & \multicolumn{2}{|c|}{ Heterotrophic bacteria } & \multicolumn{2}{|c|}{ Prochlorococcus sp. } & \multicolumn{2}{|c|}{ Synechococcus sp. } & \multicolumn{2}{|c|}{ Eukaryotic algae } \\
\hline & $\%$ cells & $\%$ DNA & $\%$ cells & $\%$ DNA & $\%$ cells & $\%$ DNA & $\%$ cells & $\%$ DNA \\
\hline st 300 & $81.5 \pm 1.1$ & $63.7 \pm 1.6$ & $18.3 \pm 1.1$ & $35.7 \pm 1.6$ & $0.1 \pm 0.01$ & $0.2 \pm 0.01$ & $0.1 \pm 0.01$ & $0.4 \pm 0.08$ \\
\hline st400 & $77.1 \pm 2.2$ & $57.0 \pm 3.0$ & $22.2 \pm 2.3$ & $40.9 \pm 3.2$ & $0.7 \pm 0.19$ & $1.4 \pm 0.42$ & $0.1 \pm 0.02$ & $0.8 \pm 0.11$ \\
\hline st 500 & $80.3 \pm 0.5$ & $61.4 \pm 0.7$ & $18.9 \pm 0.7$ & $36.1 \pm 1.3$ & $0.6 \pm 0.40$ & $1.4 \pm 0.89$ & $0.2 \pm 0.01$ & $1.2 \pm 0.06$ \\
\hline
\end{tabular}

Table 6. Relative contribution, in cell numbers and amount of DNA, of the species groups from Table 5 subdivided into 2 size classes. Assumed is that all the small heterotrophic bacteria and Prochlorococcus sp. were present on the $0.2 \mu \mathrm{m}$ filter and the Synechococcus sp. and eukaryotic algae on the $1 \mu \mathrm{m}$ filter

\begin{tabular}{|c|c|c|c|c|c|c|c|c|}
\hline \multirow[t]{3}{*}{ Stn } & \multicolumn{4}{|c|}{$0.2 \mu \mathrm{m}$ filter } & \multicolumn{4}{|c|}{$1 \mu \mathrm{m}$ filter } \\
\hline & \multicolumn{2}{|c|}{ Heterotrophic bacteria } & \multicolumn{2}{|c|}{ Prochlorococcus sp. } & \multicolumn{2}{|c|}{ Synechococcus sp. } & \multicolumn{2}{|c|}{ Eukaryotic algae } \\
\hline & $\%$ cells & $\%$ DNA & $\%$ cells & $\%$ DNA & $\%$ cells & $\%$ DNA & $\%$ cells & $\%$ DNA \\
\hline st 300 & $81.7 \pm 1.1$ & $64.1 \pm 1.6$ & $18.3 \pm 1.1$ & $35.9 \pm 1.6$ & $62.3 \pm 4.4$ & $35.3 \pm 4.2$ & $37.7 \pm 4.4$ & $64.7 \pm 4.2$ \\
\hline st 400 & $77.7 \pm 2.3$ & $58.2 \pm 3.2$ & $22.3 \pm 2.3$ & $41.8 \pm 3.2$ & $83.6 \pm 7.4$ & $63.7 \pm 11$ & $16.4 \pm 7.4$ & $36.3 \pm 11$ \\
\hline st500 & $81.0 \pm 0.7$ & $63.0 \pm 1.0$ & $19.0 \pm 0.7$ & $37.0 \pm 1.0$ & $73.2 \pm 14$ & $49.6 \pm 17$ & $26.8 \pm 14$ & $50.4 \pm 17$ \\
\hline
\end{tabular}

depth of the wind-mixed layer exceeded the actual depth of the sample locations (Anna Bay and Pest Bay) the real depth was used.

At the central Atlantic stations the mean BED in the wind-mixed layer varied between 118 and $250 \mathrm{~J} \mathrm{~m}^{-2} \mathrm{~d}^{-1}$. The highest $B E D_{m}$ was found at $\operatorname{Stn} 500$ due to the relatively shallow wind-mixed layer. The mean BEDs as calculated for the stations off Curaçao were much higher due to the high daily doses at the surface, except in the eutrophic Anna Bay, where the high attenuation coefficient $\left(1.6 \mathrm{~m}^{-1}\right)$ caused a very low BED $\mathrm{m}$ (Table 3).

\section{DNA damage in field samples}

We detected thymine dimers in DNA in all field samples collected in the central Atlantic Ocean and off Curaçao. Values varied from $20 \mathrm{CPDs} / 10^{6}$ nucleotides in the 0.2 to $1 \mu \mathrm{m}$ fraction collected in the central Atlantic Ocean to almost 0 in some samples collected in Anna Bay and Pest Bay off Curaçao (Fig. 3).

No clear relationship was found between sample depth and amount of CPDs, except for Stn 500, where there seemed to be a trend with depth. This station was characterized by strong stratification of the water column with a wind-mixed layer of only $7.5 \mathrm{~m}$. At the other stations the calculated wind-mixed layer exceeded the sample depth.

Occasionally samples were taken in the morning and evening. No significant trend was seen during the day (data not shown).
There was a significant difference (2-way ANOVA without replication, $\mathrm{p}<0.001$ ) between the amount of CPDs detected in the 2 size fractions. We detected Inore photoproducts in DNA isolated from the $0.2 \mu \mathrm{m}$ filters (Fig. 3A) than in DNA isolated from the $1 \mu \mathrm{m}$ filters (Fig. 3B).

\section{DISCUSSION}

Clearly, our method of CPD detection is a sensitive tool to detect low amounts of DNA damage in natural plankton samples. No or negligible signals were found in non-UVBR-exposed cultures of Synechococcus cells and in some field samples, excluding aspecific binding of antibody to isolated DNA.

The results demonstrate that bacterio- and phytoplankton undergo UVBR stress in the field via CPD induction (Fig. 3). Even though UVAR may induce CPDs as well, this occurs at a very slow rate, being several orders of magnitude lower than those induced as a result of UVBR exposure (Giacomoni 1995). Moreover, CPD induction by UVAR could not be detected in living phytoplankton cells (Buma et al. 1997). Generally, CPD numbers were low compared to the damage found in the culture experiments. Although the culture experiments demonstrated the vulnerability of a single species whereas in the field more resistant or sensitive species/clones may prevail, the amount of CPDs measured in field samples from the same size fraction as Synechococcus cells 

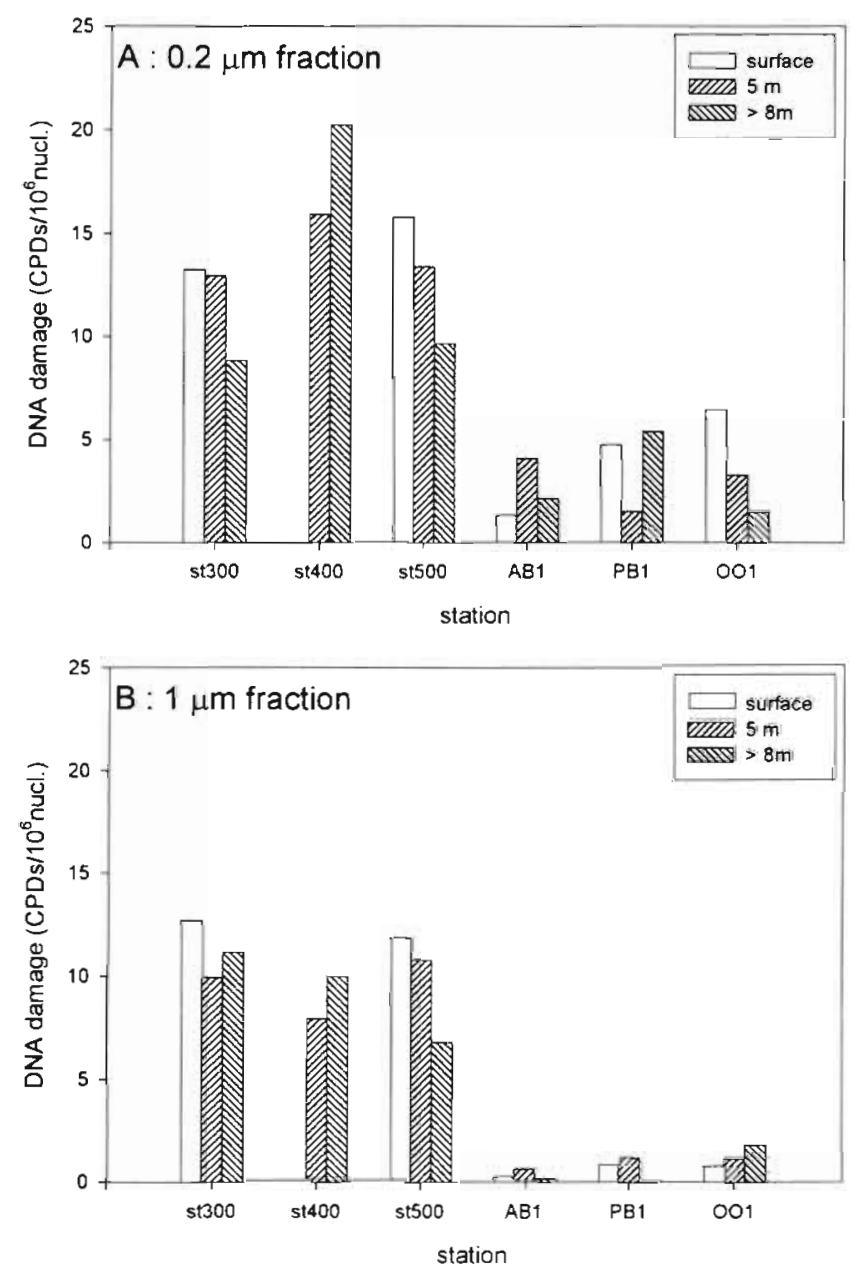

Fig. 3. DNA damage (CPDs) measured in 2 different size fractions of field samples collected between 13:00 and 16:00 h at several depths. Samples were collected between 0 and $2 \mathrm{~m}$ depth (surface), at $5 \mathrm{~m}$ depth $(5 \mathrm{~m})$ and at $15 \mathrm{~m}$ depth, except for AB1 (Anna Bay), where samples were taken at $8 \mathrm{~m}$ depth $(>8 \mathrm{~m})$. At Stn 400 no surface samples were collected $(0.2 \mu \mathrm{m}$ fraction: fraction between 0.2 and $1 \mu \mathrm{m} ; 1 \mu \mathrm{m}$ fraction: fraction between 1 and $10 \mu \mathrm{m}$ ). For information on sampling stations, codes and dates see Table 1

(1 to $10 \mu \mathrm{m}$, Fig. 3b) corresponded to CPD levels induced in Synechococcus cultures exposed to the lowest UVBR doses (up to $900 \mathrm{~J} \mathrm{~m}^{-2} \mathrm{~d}^{-1}$, Fig. 2). This is not surprising because the calculated mean BEDs in the mixed layer are much lower as compared to incident UVBR doses: the maximal BED。 was $2263 \mathrm{~J}$ $\mathrm{m}^{-2} \mathrm{~d}^{-1}$, whereas the maximal $B E D_{\mathrm{m}}$ was only $569 \mathrm{~J}$ $\mathrm{m}^{-2} \mathrm{~d}^{-1}$. This emphasizes the importance of including mixing phenomena in UVBR effect studies: even though incident UVBR doses at these latitudes may be high, the extent of mixing strongly reduces the UVBR level experienced by plankton cells collected from surface waters. On the other hand, cells mixed from deeper waters, for instance close to the $1 \%$
UVBR depth, to shallower depths, will experience elevated UVBR levels. In this way, damage is distributed throughout the whole mixed layer.

Comparable low amounts of DNA damage were measured by Visser et al. (1999) in field samples collected off Curaçao and in Antarctic zooplankton collected by Malloy et al. (1997). Jeffrey et al. (1996b) measured DNA damage in bacterio- and phytoplankton in the Gulf of Mexico combined with DNA dosimeter measurements. While Jeffrey et al. (1996b) measured comparable BEDs, the number of CPDs they found in bacterioplankton was much higher (up to 400 $\mathrm{CPDs} / \mathrm{Mbp} \mathrm{DNA} \equiv 200 \mathrm{CPDs} / 10^{6}$ nucleotides) than the levels found in our study. Besides differences in sampling procedures, DNA isolation and DNA damage quantification methods, seasonal variations, differences in species composition and mixing depth could explain the discrepancies in the results.

Since the depth of the wind-mixed layer exceeded the sample depth at most stations, depth-dependent trends in photodamage were not expected, and were not observed. Only at Stn 500, a decreasing trend with depth was found (Fig. 3). Here, the calculated windmixed layer was only $7.5 \mathrm{~m}$.

We measured a significant difference between the number of CPDs detected in the 2 size fractions. In DNA isolated from the 0.2 to $1 \mu \mathrm{m}$ fraction, consisting mainly of heterotrophic bacteria and prochlorophytes, more photoproducts were detected compared to the 1 to $10 \mu \mathrm{m}$ fraction (mainly Synechococcus sp. and eukaryotic algae). Similar differences were found by Jeffrey et al. (1996b) in samples collected in the Gulf of Mexico. This effect can be explained by differences in cell size. Karentz et al. (1991) found a positive trend between surface area:volume ratio and photoproduct induction in cultures of Antarctic phytoplankton. Additionally, Garcia-Pichel (1994) calculated that picoplankton, due to their small cell size, can not efficiently use UVR-absorbing compounds, such as mycosporinelike amino acids. Therefore, smaller organisms would have less ability to protect themselves from UVR damage.

Generally, the amount of DNA damage was higher in the central Atlantic Ocean than at the stations off Curaçao (Fig. 3). These differences cannot be explained by the amount of UVBR the plankton received at the sample locations. Despite the fact that the penetration of UVBR into the water column was lower at Curaçao, the mean biologically effective doses were higher, except at the eutrophic Anna Bay (Table 3). Differences in photorepair rate may have played a role as well. Although speculative, photorepair rates may not have been optimal at all stations. Since photorepair depends on levels of UVAR and PAR (Friedberg et al. 1995), the final amount of residual CPDs as measured 
in the samples will depend on the UVAR/UVBR and PAR/UVBR ratios experienced by the cells. At Curaçao, UVBR levels were higher than at the central Atlantic stations. It is highly likely that incident UVAR and PAR were also higher at Curaçao. Finally, UVARPAR:UVBR ratios could be higher as well, due to differences in water characteristics such as yellow substance concentration (Boelen et al. 1999). Thereby residual DNA damage could be lower at these locations.

Another possibility for the lower amount of DNA damage found at the stations near Curaçao is a difference in species composition. The ratio of cyanobacteria to eukaryotic algae, in terms of chlorophyll a concentrations, at the Atlantic stations was higher than at the stations off Curaçao (Table 4). This implies that at the stations near Curaçao relatively more of the total amount of DNA in the 1 to $10 \mu \mathrm{m}$ fraction originated from larger eukaryotic phototrophic organisms. Since large cells are generally less sensitive to UVBR, less DNA damage may have occurred at these stations. At the central Atlantic stations most of the cellular DNA in the surface layer originated from small marine heterotrophic bacteria and Prochlorococcus sp. (Table 5). These results correspond to those of Paul et al. (1985) that most ( 70 to $99 \%$ ) of the particulate DNA in offshore samples is in the 0.2 to $1 \mu \mathrm{m}$ fraction. No flow cytometer samples were collected at the stations off Curaçao, but bacterial numbers at the Atlantic stations (results not shown) were comparable with bacterial numbers found in 1994 and 1995 near Curaçao by Gast et al. (1998). Since the amount of (divinyl-jchlorophyll a contributed by prochlorophytes was higher at the OO1 and PB1 stations than in the central Atlantic Ocean (Table 4), more prochlorophytes relative to heterotrophic bacteria were collected on the $0.2 \mu \mathrm{m}$ filters. This relatively higher amount of prochlorophytes could be responsible for the lower amount of DNA damage found at these stations.

In conclusion, our results demonstrate that the amount of CPDs in a population is difficult to predict from incident irradiances. Also, given the differences found between the 2 size fractions, it is of major importance to distinguish between various species groups. Likely mixing phenomena play an important role in the occurrence of UVBR stress in marine organisms. Neale et al. (1998) calculated interactive effects of ozone depletion and vertical mixing on UVR-mediated inhibition of photosynthesis. They showed that UVBR stress may either be diminished or enhanced, depending on the mixing depth. Our next objective is to study the effect of wind-induced, vertical mixing on the rate of DNA damage formation. This will be done by excluding mixing by in situ incubation experiments at several. depths.
Acknowledgements. The authors wish to thank P. M. Visser I. Obernosterer and the Ecological Institute CARMABI at Curaçao for technical assistance, A.A. Vink for the $\mathrm{H} 3$ antibody and W.W.C. Gieskes for critical reading of the manuscript. The field research was partly sponsored by the Netherlands Organization for the Advancement of Research (NWO). This is NIOZ publication number 3373

\section{LITERATURE CITED}

Aas P, Lyons MM, Pledger R, Mitchell DL, Jeffrey WH (1996) Inhibition of bacterial activities by solar radiation in nearshore waters and the Gulf of Mexico. Aquat Microb Ecol 11:229-238

Behrenfeld M, Hardy J, Gucinski H, Hanneman A, Lee HI, Wones A (1993) Effects of ultraviolet-B radiation on primary production along latitudinal transects in the South Pacific Ocean. Mar Environ Res 35:349-363

Boelen P, Obernosterer I, Vink AA, Buma AGJ (1999) Attenuation of biologically effective $U V$ radiation in tropical Atlantic waters, as measured with a biochemical DNA dosimeter. Photochem Photobiol 69:34-40

Buma AGJ, van Hannen EJ, Roza L, Veldhuis MJW, Gieskes WWC (1995) Monitoring ultraviolet-B-induced DNA damage in individual diatom cells by inmunofluorescent thymine dimer detection. J Phycol 31:314-321

Buma AGJ, Engelen AH, Gieskes WWC (1997) Wavelengthdependent induction of thymine dimers and growth rate reduction in the marine diatom Cyclotella sp. exposed to ultraviolet radiation. Mar Ecol Prog Ser 153:91-97

Doyle JJ, Doyle JL. (1991) Isolation of plant DNA from fresh tissue. Focus 12:13-15

Drollet JH, Glaziou P, Martin PMV (1993) A study of mucus from the solitary coral Fungia fungites (Scleractinia: Fungiidae) in relation to photobiological UV adaptation. Mar Biol 115:263-266

Fekete A, Vink AA, Gaspar S, Berces A, Modos K, Ronto G, Roza L (1998) Assessment of the effects of various UV sources on inactivation and photoproduct induction in phage T7 dosimeter. Photochem Photobiol 68:527-531

Friedberg EC, Walker GC, Siede W (1995) DNA repair and mutagenesis. ASM Press, Washington, DC

Garcia-Pichel F (1994) A model for internal self-shading in planktonic organisms and its implications for the usefulness of ultraviolet sunscreens. Limnol Oceanogr 39: $1704-1717$

Gast GJ, Wiegman S, Wieringa E, van Duyl FC, Bak RPM (1998) Bacteria in coral reef water types: removal of cells, stimulation of growth and mineralization. Mar Ecol Prog Ser $167: 37-45$

Giacomoni PU (1995) Open questions in photobiology: II. Induction of nicks by UV-A. J Photochem Photobiol B Biol 29:83-85

Guillatd RRL (1975) Culture of phytoplankton for feeding marine invertebrates. In: Smith WL, Chanley MH (eds) Culture of marine invertebrate animals. Plenum Press, New York, p 29-60

Helbling EW: Villafane V, Holm-Hansen O (1994) Effects of ultraviolet radiation on Antarctic marine photosynthesis with particular attention to the influence of mixing. In: Weiler CS, Penhale PA (eds) Ultraviolet radiation in Antarctica: measurements and biological effects. Antarctic Res Ser 62, American Geophysics Union, Washington DC, p 207-229

Jeffrey WH, Aas P, Lyons MM, Coffin RB, Pledger RJ, Mitchell DL (1996a) Ambient solar radiation-induced photo- 
damage in marine bacterioplankton. Photochem Photobiol $64: 419-427$

Jeffrey WH, Pledger RJ, Aas $\mathrm{P}$, Hager $\mathrm{S}$, Coffin RB, von Haven R, Mitchell DL (1996b) Diel and depth profiles of DNA photodamage in bacterioplankton exposed to ambient solar ultraviolet radiation. Mar Ecol Prog Ser 137: 283-291

Karentz D, Cleaver JE, Mitchell DL (1991) Cell survival characteristics and molecular responses of Antarctic phytoplankton to ultraviolet-B radiation. J Phycol 27: $326-341$

Kraay GW, Zapata M, Veldhuis MJW (1992) Separation of chlorophylls $c 1, c 2$ and $c 3$ of marine phytoplankton by reversed-phase-c18-high-performance liquid chromatography. J Phycol 28:708-712

Lyons MM, Aas P, Pakulski JD, van Waasbergen L, Miller RV, Mitchell DL, Jeffrey WH (1998) DNit damage induced by ultraviolet radiation in coral-reef microbial communities. Mar Biol 130:537-543

Mackey MD, Mackey DJ, Higgins HW, Wright SW (1996) CHEMTAX - a program for estimating class abundances from chemical markers: application to HPLC measurements of phytoplankton. Mar Ecol Prog Ser 144: $265-283$

Malloy KD, Holman MA, Mitchell D, Detrich HW (1997) Solar UVB-induced DNA damage and photoenzymatic DNA repair in Antarctic zooplankton. Proc Natl Acad Sci USA 94:1258-1263

Neale PJ, Davis RF, Cullen JJ (1998) Interactive effects of ozone depletion and vertical mixing on photosynthesis of Antarctic phytoplankton. Nature 392:585-589

Paul JH, Jeffrey WH, DeFlaun M. (1985) Particulate DNA in subtropical oceanic and estuarine planktonic environments. Mar Biol 90:95-101

Roza L, van der Wulp KJM, McFarlane SJ, Lohman PHM, Baan RA (1988) Detection of cyclobutane thymine dimers in DNA of human cells with monoclonal antibodies raised against a thymine dimer-containing tetranucleotide. Photochem Photobiol 48:627-633

Setlow RB, Swenson PA, Carrier WL (1963) Thymine dimers

Editorial responsibility: Otto Kinne (Editor), Oldendort/Luhe, Germany and inhibition of DNA synthesis by ultraviolet radiation of cells. Science 142:1464-1465

Setlow RB (1974) The wavelengths in sunlight effective in producing skin cancer: a theoretical analysis. Proc Nat Acad Sci USA 71:3363-3366

Shibata K (1969) Pigments and a UV-absorbing substance in corals and a blue-gree alga living in the Great Barrier Reef. Plant Cell Physiol 10:325-335

Smith RC, Baker KS (1979) Penetration of UV-B and biologically effective dose-rates in natural waters. Photochem Photobiol 29:311-323

Swenson PA, Setlow RB (1966) Effects of ultraviolet radiation on macromolecular synthesis in Escherichia coli. J Mol Biol 15:201-219

Tyrrell RM (1986) Repair of genetic damage induced by UV-B $(290-320 \mathrm{~nm})$ radiation. In: Worrest $\mathrm{RC}$, Caldwell MM (eds) Stratospheric ozone reduction, solar ultraviolet radiation and plant life. Springer-Verlag, Berlin, p 139-149

Veldhuis MJW, Kraay GW (1990) Vertical distribution and pigment composition of a picoplanktonic prochlorophyte in the subtropical North A.tlantic: a combined study of HPLC-analysis of pigments and flow cytometry. Mar Ecol Prog Ser 68:121-127

Veldhuis MJW, Cucci TL, Sieracki ME (1997) Cellular DNA content of marine phytoplankton using two new fluorochromes: Taxonomic and ecological implications. J Phycol 33:527-541

Veth $C$ (1991) The evolution of the upper water layer in the marginal ice zone, austral spring 1988, Scotia-Weddell Sea. J Mar Syst 2:451-464

Visser PM, Snelder E, Kop AJ, Boelen P, Buma AGJ, Van Duyl FC (1999) Effects of UV radiation on DNA photodamage and production in bacterioplankton in the coastal Caribbean Sea. Aquat Microb Ecol 20:49-58

Wilhelm SW, Weinbauer MG, Suttle CA, Pledger RJ, Mitchell DL (1998) Measurements of DNA damage and photoreactivation imply that most viruses in marine surface waters are infective. Aquat Microb Ecol 14:215-222

Wood WF (1987) Effect of solar ultra-violet radiation on the kelp Ecklonia radiata. Mar Biol 96:143-150

Submitted: April 15, 1999; Accepted: September 6, 1999 Proofs received from author(s): February 2, 2000 